\title{
SOCIAL REPRODUCTION AND ANEMIA IN INFANCY ${ }^{1}$
}

\author{
Elizabeth Fujimori ${ }^{2}$ \\ Luciane Simões Duarte ${ }^{3}$ \\ Áurea Tamami Minagawa ${ }^{4}$ \\ Daniela Laurenti ${ }^{5}$ \\ Rosali Maria Juliano Marcondes Montero ${ }^{6}$
}

Fujimori E, Duarte LS, Minagawa AT, Laurenti D, Montero RMJM. Social reproduction and anemia in infancy. Rev Latino-am Enfermagem 2008 março-abril; 16(2):245-51.

This study assessed the relationship between anemia in infancy and the social reproduction profile of the families. It was conducted with a representative sample of 254 children of the city of Itupeva, SP. Hemoglobin $<11 \mathrm{~g} / \mathrm{dL}$, determined by portable hemoglobin analyzer, was used to define anemia. Profiles of social reproduction had been built by 2 groups of indicators: working and living conditions. Three social homogeneous groups had been defined: upper, intermediate, lower. Anemia was prevalent in $41.7 \%$, and more frequent in lower social groups $(13.2 \% ; 40.6 \% ; 46.2 \%)$, but with no significant difference $(p>0.05)$. However, profile of social reproduction of anemic families showed significant difference $(p<0.05)$. Occurrence of anemia was related to poor working conditions in lower social groups and consequently inappropriate living conditions.

DESCRIPTORS: social group; anemia; child

\section{REPRODUCCIÓN SOCIAL Y ANEMIA INFANTIL}

Se evaluó como la anemia infantil se relaciona con las formas de reproducción social. El estudio fue desarrollado en una muestra representativa de 254 niños que vivían en Itupeva, SP. Para definir la anemia se usó el nivel de Hemoglobina $<11 \mathrm{~g} / \mathrm{dL}$, determinada por un medidor de hemoglobina portátil. Se construyeron perfiles de reproducción social a través de 2 conjuntos de indicadores: formas de trabajar y formas de vivir. Se definieron 3 estratos sociales homogéneos: superior, intermedio e inferior. La prevalencia para la anemia fue de $41,7 \%$, siendo de mayor frecuencia en los estratos inferiores (13,2\%; 40,6\%; 46,2\%), no presentando diferencia estadística $(p>0,05)$. El perfil de reproducción social en las familias de pacientes anémicos, mostró diferencia significativa $(p<0,05)$. La presencia de anemia en los estratos inferiores, estuvo asociada a las condiciones precarias de trabajo; siendo una consecuencia para las inadecuadas condiciones de vivir.

DESCRIPTORES: grupo social; anemia; niño

\section{REPRODUÇÃO SOCIAL E ANEMIA INFANTIL}

Este estudo avaliou como a anemia infantil se relaciona com as formas de reprodução social das famílias. Foi desenvolvido em amostra representativa de 254 crianças. residentes em Itupeva, SP. Hemoglobina <11g/dL, determinada em hemoglobinômetro portátil, foi utilizada para definir anemia. Construiu-se perfis de reprodução social com 2 conjuntos de indicadores: formas de trabalhar e formas de viver. Definiu-se 3 estratos sociais homogêneos: superior, intermediário, inferior. A prevalência de anemia foi de $41,7 \%$, sendo mais freqüente nos estratos inferiores $(13,2.40,6$ e 46,2\%), mas sem diferença estatística ( $p>0,05)$. O perfil de reprodução social das famílias dos anêmicos mostrou diferença significativa $(p<0,05)$. Observou-se que a ocorrência da anemia atrelou-se às precárias formas de trabalhar dos estratos sociais inferiores e, conseqüentemente, inadequadas formas de viver.

DESCRITORES: grupo social; anemia; criança

\footnotetext{
${ }^{1}$ Study funded by the National Council for Scientific and Technological Development, CNPq, Process no 478872/2004-6; ${ }^{2}$ PhD in Public Health, Associate Professor, e-mail: efujimor@usp.br; ${ }^{3}$ Nursing undergraduate student. University of São Paulo, School of Nursing, Brazil; ${ }^{4}$ Doctoral Student, University of São Paulo, School of Nursing, Professor at Faculty of Medical Sciences of Santa Casa Sao Paulo, Brazil; ${ }^{5}$ M.Sc. in Nursing; ${ }^{6}$ M.Sc. in Nursing, RN, Secretary of Health, Itupeva City Administration, Brazil
} 


\section{INTRODUCTION}

Iron deficiency anemia is the most common nutritional disorder worldwide. However, its magnitude is higher in the poorest regions, where about $40 \%$ of the children below 4 years old are anemic, a proportion twofold greater than that estimated for industrial countries $^{(1)}$.

In Brazil, children present extremely high prevalence of anemia, reaching up proportions even higher than $40 \%{ }^{(2-5)}$. In epidemiological terms, this fact highlights anemia as a serious public health problem $^{(1)}$. In the city of São Paulo, the prevalence was $22.7 \%$ in the 70 's, $35.6 \%$ in the 80 's, and $46.9 \%$ in the following decade ${ }^{(6)}$.

The recognized relevance of anemia is not only because of the magnitude of its prevalence, but mainly due to the deleterious effects that it leads to. In children it has been associated with psychological and motor development retardation, compromised cellular immunity, and decrease in the intellectual capacity, with effects in cognitive development ${ }^{(1)}$.

In the body, anemia occurs from the inability of the erythropoietic tissue to keep a normal hemoglobin concentration, because of poor iron supply. Thus, anemia is defined as a state in which abnormally low hemoglobin concentration results from a previous iron deficiency that led to depletion of iron stores $^{(1)}$. In this perspective, iron deficiency is an organic problem resulting from biological processes; it is consequence of poor iron absorption and/or depletion of this mineral. However, its occurrence has been associated with adverse social and economic conditions frequently due to inadequate food intake and depletion from parasitic infestation, in places where sanitation is $\operatorname{poor}^{(7)}$.

The field of collective health sees healthdisease process as socially determined. In this view, articulation between the social and the biologic occurs through social reproduction, that is, through the way each social group is inserted in work and life ${ }^{(8)}$. The categories to study and explain how the social process interferes in collective health-disease relate to the forms of social insertion, that concern both ways of working and ways of living, with positive or negative impacts in individuals exposing them to different risks to fall ill and to die.

The present study was structured under the theory of social determination of the health-disease process. The objective was to assess how infant anemia is related to the forms of social reproduction of the families.

\section{METHODOLOGY}

This is a descriptive analytical cross sectional study that assessed data from a broader project called "Prevalência de anemia e fatores de risco em crianças menores de dois anos de idade" ("Prevalence of anemia and risk factors in children below 2 years of age"), developed in the city of Itupeva, SP, Brazil. In this greater study, the sample size was calculated based on an estimate of the number of children below 2 years of age, the number of houses in the urban area of the city, and considered estimated prevalence of anemia at $45 \%$ in order to assure representativeness of the population ${ }^{(6)}$. Based on the procedure of conglomerate samples, a sample size of 274 children was obtained, error accepted was up to $5 \%$, and the prediction for losses and refusals was $10 \%$. Randomization was performed into 3 stages (census sectors, blocks, and individual households) and the final sample was composed of 261 children. Hemoglobin measure was obtained from 254 children.

A pilot study was performed into around 10 families. At this time, instrument of interview was tested and the logistic of field work was put into practice to assess its performance. For data collection, household interviews were performed between July/ August 2001 by nurses and trained nursing students. The instrument of interview included closed questions with details on ways of working and living, as well as biological and health data.

Profiles of the social reproduction of the families were characterized using theoretical, methodological, and operational bases ${ }^{(9)}$. This base pre defines three homogeneous social groups with similar ways of working and living. Based on this proposal, two sets of indicators were used. In order to represent family insertion at the time of social production (ways of working), cutoff variables used were: per capita family income (PCFI), formal work, and use of benefits from work. In order to represent family insertion at the time of social reproduction or consumption (ways of living), cutoff variables used were: household ownership, leisure activity, and group of social aggregation (social life). Families that have fulfilled at least 2 of the following attributes 
were considered as having appropriate ways of working: PCFI $\geq 1.8$ minimum wage; one family member with formal employment, and use of 2 or more benefits, being one of them related to health. Families that have fulfilled at least 2 of the following attributes were considered as having appropriate ways of living: household ownership; one member with leisure activity unrelated to TV/VCR, and one family member taking part in community or political associations. Three homogeneous social groups were defined from these indicators and cutoff variables: upper group, with families presenting appropriate ways of working and living; intermediate group, including families with appropriate ways of working and inappropriate ways of living or vice versa; and a lower group, with families with inappropriate ways of working and living.

Anemia was diagnosed based on the concentration of hemoglobin ( $\mathrm{Hb}$ ) determined by HemoCue system, which with only one drop of capillary blood presents the immediate result on the screen. $\mathrm{Hb}$ concentration $<11.0 \mathrm{~g} / \mathrm{dL}$ was used as a cut off point to define anemia(1).

The broader research was approved by the Ethical Research Committee of the School of Nursing of the University of São Paulo. Blood sample was only obtained after written consent was given by mothers/ responsible, and the $\mathrm{Hb}$ result was returned to the family. Anemic children were sent to a reference health unit as previously agreed with the Municipal Health Agent.

Data were analyzed using Epi-Info program version 6.04 and the module Epi-Nut to assess the nutritional state. Chi-square test $\left(\chi^{2}\right)$ was used to analyze the difference between categorical variables, and variance analysis (ANOVA) was used for statistical comparison between averages. A $p<0.05$ was considered statistically significant.

\section{RESULTS}

Anemia prevalence was $41.7 \%$. Table 1 shows that the distribution of children according to anemia and social groups was considerably heterogeneous, however, no statistical significance was observed $(p>0.05)$. Frequency of anemic children was less observed in families in the upper group (13.2\%), while $40.6 \%$ of anemic children belonged to families in the intermediate group, and $46.2 \%$ in the lower group.
Table 1 - Distribution of children according to anemia and social group. Itupeva, SP, 2001

\begin{tabular}{lccccc}
\hline \multirow{2}{*}{ Anemia } & \multicolumn{3}{c}{ Social group } & Total & \multirow{2}{*}{ * } \\
& $\mathbf{n}(\%)$ & $\mathbf{n}(\%)$ & $\mathbf{n}(\%)$ & $\mathbf{n ~ ( \% )}$ & \\
\hline Yes & $14(13.2)$ & $43(40.6)$ & $49(46.2)$ & $106(100.0)$ & 0.212 \\
No & $32(21.6)$ & $51(34.4)$ & $65(43.9)$ & $148(100.0)$ & \\
\hline \multicolumn{1}{c}{ Total } & $\mathbf{4 6 ( 1 8 . 1 )}$ & $\mathbf{9 4 ( 3 7 . 0 )}$ & $\mathbf{1 1 4 ( 4 4 . 9 )}$ & $\mathbf{2 5 4 ( 1 0 0 . 0 )}$ & \\
\hline
\end{tabular}

*Chi-square test

Table 2 summarizes the main characteristics of the profiles in social reproduction found in the families with anemic children, categorized according to cutoff variables used to make the three social groups. Although the proportion of families with PCFI $\geq 1.8$ minimum wage did not show statistical significant difference among the groups, the insertion in regular jobs, referred by all families in the upper group, showed to be less than a half in the lower group $(p<0.05)$. The same was observed considering work benefits, not present in the lower group. Household ownership, referred by almost all families in the upper group, decreased by half in the intermediate group, and less than one fourth in the lower group $(p<0.05)$, whereas social aggregation, smaller in the upper group (50\%), was practically null in the lower group.

Table 2 - Distribution of families of anemic children, according to cutoff variables that composes the three social groups. Itupeva, SP, 2001

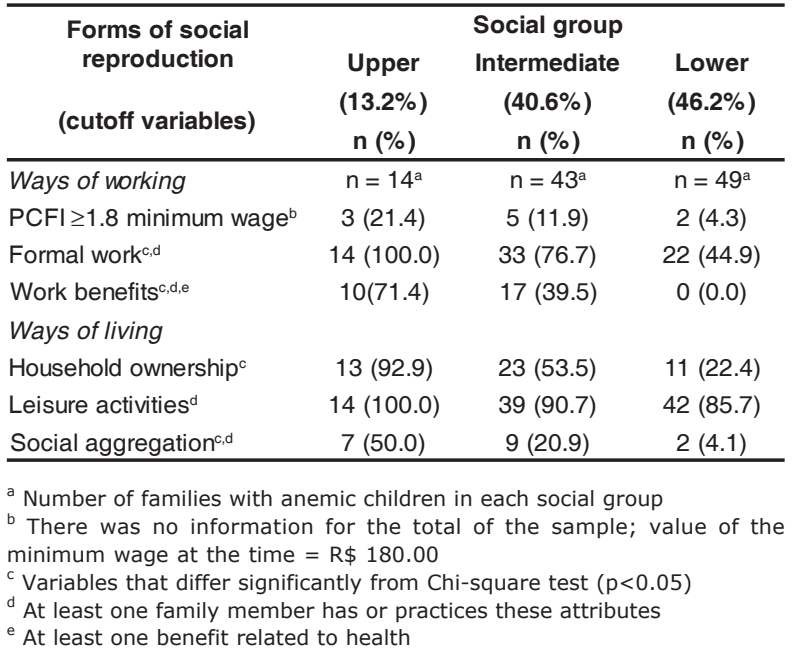

Table 3 shows that the ways of insertion in work and in life differed considerably among the three groups. Mean PCFI was significantly different among the social groups, as well as the activity sectors, and position in work. In upper and intermediate 
groups almost all families lived in houses with a bathroom inside the household and had public sanitation, which was not observed in the lower group. Home utilities and reading (one of the measures of leisure activity) also showed to be different among the groups.

Table 3 - Distribution of families of anemic children, according to ways of working and living and social groups. Itupeva, SP, 2001

\begin{tabular}{|c|c|c|c|c|}
\hline \multirow[b]{2}{*}{$\begin{array}{l}\text { Ways of working and } \\
\text { living }\end{array}$} & \multicolumn{3}{|c|}{ Social Groups } & \multirow[b]{2}{*}{$\mathbf{p}^{\mathbf{a}}$} \\
\hline & $\begin{array}{l}\text { Upper } \\
\text { n (\%) }\end{array}$ & $\begin{array}{c}\text { Intermediate } \\
\text { n (\%) }\end{array}$ & $\begin{array}{l}\text { Lower } \\
\mathbf{n}(\%)\end{array}$ & \\
\hline Ways of working ${ }^{b}$ & $n=24^{c}$ & $\mathrm{n}=75^{\mathrm{c}}$ & $\mathrm{n}=74^{\mathrm{c}}$ & \\
\hline \multicolumn{5}{|l|}{ PCFI } \\
\hline $\mathrm{X} \pm \mathrm{SD}$ & $149.8 \pm 101.4$ & $134.6 \pm 112.6$ & $98.8 \pm 72.2$ & $0.028^{d}$ \\
\hline \multicolumn{5}{|l|}{ Activity sector } \\
\hline Industry & 7 (33.2) & $26(39.4)$ & $14(22.2)$ & \\
\hline Civil construction & $1(4.8)$ & $7(10.6)$ & $16(25.4)$ & \\
\hline Retailing & $1(4.8)$ & $6(9.1)$ & $1(1.6)$ & 0.027 \\
\hline General senvices & $11(52.4)$ & $19(28.8)$ & $19(30.2)$ & \\
\hline Domestic senvices & $1(4.8)$ & $6(9.1)$ & $12(19.0)$ & \\
\hline Other & $0(0.0)$ & $2(3.0)$ & $1(1.6)$ & \\
\hline \multicolumn{5}{|l|}{ Position in the occupation } \\
\hline Receive a salary & 20 (95.2) & $58(87.9)$ & $38(60.3)$ & 0.005 \\
\hline Autonomous & $1(4.8)$ & $8(12.1)$ & $23(36.5)$ & \\
\hline Employer & $0(0.0)$ & $0(0.0)$ & $2(3.2)$ & \\
\hline \multicolumn{5}{|l|}{ Work shift } \\
\hline$\leq 5$ days/week & $15(71.4)$ & $33(50.8)$ & 27 (42.9) & 0.076 \\
\hline$>5$ days/week & $6(28.6)$ & 32 (49.2) & $36(57.1)$ & \\
\hline Ways of living & $n=14^{e}$ & $n=43^{e}$ & $n=49^{e}$ & \\
\hline \multicolumn{5}{|l|}{ Characteristics of households } \\
\hline $\begin{array}{l}\text { Bathroom inside the } \\
\text { house }\end{array}$ & $14(100.0)$ & $43(100.0)$ & $40(81.6)$ & 0.003 \\
\hline \multicolumn{5}{|l|}{ Access to public services } \\
\hline Piped water & $13(92.9)$ & $42(97.7)$ & $35(71.4)$ & 0.001 \\
\hline Sewage & $13(92.9)$ & $41(95.3)$ & $36(73.5)$ & 0.009 \\
\hline Garbagge & $14(100.0)$ & $43(100.0)$ & 47 (95.9) & 0.305 \\
\hline \multicolumn{5}{|l|}{ Having home utilities } \\
\hline Refrigerator & $14(100.0)$ & $40(93.0)$ & 47 (95.9) & 0.043 \\
\hline \multicolumn{5}{|l|}{ Leisure activities } \\
\hline Reading & $5(35.7)$ & $15(34.9)$ & $7(14.3)$ & 0.049 \\
\hline
\end{tabular}

Social groups were also different in relation to sociodemographic data. Table 4 shows that mean age of head of households, educational level of mother and of household head, number of children, and also maternal marital status were significantly different among the social groups $(p<0.05)$. On the other hand, they kept some similarities, such as the proportion of adolescent mothers, family size, and maternal insertion in the workplace.
Table 4 - Distribution of families of anemic children, according to sociodemographic data. Itupeva, SP, 2001

\begin{tabular}{|c|c|c|c|c|}
\hline \multirow[b]{2}{*}{ Sociodemographic data } & \multicolumn{3}{|c|}{ Social groups } & \multirow[b]{2}{*}{$\mathbf{p}^{\mathbf{a}}$} \\
\hline & $\begin{array}{l}\text { Upper } \\
\text { n (\%) }\end{array}$ & $\begin{array}{c}\text { Intermediate } \\
\mathbf{n}(\%)\end{array}$ & $\begin{array}{l}\text { Lower } \\
\text { n (\%) }\end{array}$ & \\
\hline $\begin{array}{c}\text { Family } \\
\text { Age of head of household }\end{array}$ & $\mathrm{n}=14^{\mathrm{b}}$ & $n=43^{b}$ & $\mathrm{n}=49^{\mathrm{b}}$ & \\
\hline $\begin{array}{l}X \pm S D \\
\text { Household head schooling }\end{array}$ & $35.0 \pm 11.3$ & $33.4 \pm 8.1$ & $28.2 \pm 6.7$ & 0.004 \\
\hline $\begin{array}{l}X \pm S D \\
\text { Number of people }\end{array}$ & $8.8 \pm 2.7$ & $7.2 \pm 2.9$ & $6.4 \pm 2.9$ & 0.023 \\
\hline $\begin{array}{l}\mathrm{X} \pm \mathrm{SD} \\
\text { Maternal } \\
\text { Age (years) }\end{array}$ & $\begin{array}{c}4.2 \pm 1.2 \\
n=14^{b}\end{array}$ & $\begin{array}{c}4.8 \pm 1.4 \\
n=43^{b}\end{array}$ & $\begin{array}{c}5.0 \pm 1.9 \\
n=49^{b}\end{array}$ & 0.394 \\
\hline $\begin{array}{l}<20 \\
\geq 20\end{array}$ & $\begin{array}{c}4(28.6) \\
10(71.4)\end{array}$ & $\begin{array}{c}5(11.6) \\
38(88.4)\end{array}$ & $\begin{array}{l}10(20.4) \\
39(79.6)\end{array}$ & $0.294^{\circ}$ \\
\hline Schooling (years of study) & & & & \\
\hline $\begin{array}{l}\mathrm{X} \pm \mathrm{SD} \\
\text { Number of children }\end{array}$ & $7.7 \pm 2.3$ & $7.0 \pm 2.3$ & $5.9 \pm 2.8$ & 0.025 \\
\hline $\begin{array}{l}\mathrm{X} \pm \mathrm{SD} \\
\text { Insertion in the workplace }\end{array}$ & $1.4 \pm 0.5$ & $2.3 \pm 1.0$ & $2.5 \pm 1.5$ & 0.014 \\
\hline $\begin{array}{l}\text { Yes } \\
\text { No }\end{array}$ & $\begin{array}{l}6(42.9) \\
8(57.1) \\
\end{array}$ & $\begin{array}{l}18(41.9) \\
25(58.1) \\
\end{array}$ & $\begin{array}{l}16(32.7) \\
33(67.3) \\
\end{array}$ & $0.604^{\mathrm{c}}$ \\
\hline
\end{tabular}

Table 5 presents anemic children characteristics according to the social group they belonged to. Despite the similarities, since statistical treatment did not show significant differences, the poorest groups presented worse nutritional status, less access to pediatric appointments, and greater frequency of respiratory problems, as well as presence of parasites.

Table 5 - Distribution of families of anemic children, according to children characteristics and social groups. Itupeva, SP, 2001

\begin{tabular}{|c|c|c|c|c|}
\hline $\begin{array}{c}\text { Children } \\
\text { characteristics }\end{array}$ & $\begin{array}{l}\text { Upper } \\
n(\%) \\
n=14^{b}\end{array}$ & $\begin{array}{c}\text { Social groups } \\
\text { Intermediate } \\
\text { n (\%) } \\
n=43^{\mathrm{b}}\end{array}$ & $\begin{array}{l}\text { lower } \\
n(\%) \\
n=49^{b}\end{array}$ & $\mathbf{p}^{\mathrm{a}}$ \\
\hline \multicolumn{5}{|l|}{ Age } \\
\hline $\mathrm{X} \pm \mathrm{SD}$ & $12.7 \pm 5.3$ & $12.3 \pm 6.5$ & $10.9 \pm 6.2$ & $0.369^{c}$ \\
\hline \multicolumn{5}{|l|}{ Sex } \\
\hline Male & $9(64.3)$ & $26(60.5)$ & $22(44.9)$ & $0.229^{\circ}$ \\
\hline Female & $5(35.7)$ & $17(39.5)$ & $27(55.1)$ & \\
\hline \multicolumn{5}{|l|}{ Height/age (score Z) } \\
\hline $\begin{array}{l}\mathrm{X} \pm \mathrm{SD} \\
\text { Weight/height (score }\end{array}$ & \multicolumn{4}{|c|}{ Weight/height (score Z) } \\
\hline \multicolumn{4}{|l|}{ Breastfeeding $^{d}$} & $0.460^{\circ}$ \\
\hline Yes & $4(28.6)$ & $14(32.6)$ & $23(50.0)$ & 0.159 \\
\hline No & $10(71.4)$ & $29(67.4)$ & $23(50.0)$ & \\
\hline \multicolumn{5}{|l|}{ Pediatric appointment } \\
\hline Yes & $14(100.0)$ & $41(95.3)$ & $41(83.7)$ & 0.069 \\
\hline No & $0(0.0)$ & $2(4.7)$ & $8(16.3)$ & \\
\hline \multicolumn{5}{|l|}{ Ferrous sulphate } \\
\hline Yes & $6(42.8)$ & $24(55.8)$ & $19(38.8)$ & 0.253 \\
\hline No & $8(57.2)$ & $19(44.2)$ & $30(61.2)$ & \\
\hline \multicolumn{5}{|c|}{ Respiratory problem (last 30 days) } \\
\hline Present & $2(14.3)$ & $8(18.6)$ & $11(22.4)$ & 0.770 \\
\hline Absent & $12(85.7)$ & $35(81.4)$ & 38 (77.6) & \\
\hline \multicolumn{5}{|l|}{ Parasites } \\
\hline Present & $0(0.0)$ & $1(2.3)$ & $2(4.1)$ & 0.695 \\
\hline Absent & $14(100.0)$ & $42(97.7)$ & $47(95.9)$ & \\
\hline
\end{tabular}




\section{DISCUSSION}

Results show that the high prevalence of anemia in the city was heterogeneously distributed among the different social groups, although statistical treatment did not show significant difference. Considering all anemic children, the frequency of children from families with appropriate ways of working and living was low (13.2\%). On the other hand, it was seen that families of anemic children, mostly, presented inappropriate situations of work or life - intermediate group $(40.6 \%)$, or those socially excluded - lower group (46.2\%).

The greatest frequency of anemia among children in lower social groups is consistent with data obtained in the city of São Paulo(10), but significant association was observed only in the severe cases of anemia, which was similar to other studies $^{(3-4)}$.

Mean income was significantly different $(p<0.05)$ among the groups. Moreover, the difference regarding insertion in formal work was also substantial, as well as sector of activity, position of workers, and benefits from work. The insertion in work determines access to income, and that income determines level of consumption and, therefore, access to goods, including household, sanitation, food, health care, school, etc. Thus, the important differences found in ways of living of the families with anemic children are justified. Regarding living conditions, both household ownership and the household conditions, such as access to basic supplies like piped water and sewage were significantly more precarious in the lower groups. Age and schooling of household heads and mothers were also different, as well as number of children in the family.

Although most studies show that infant anemia is more frequent in families with lower income ${ }^{(2-4,6)}$, this association is not always found ${ }^{(11)}$. That could be explained by the fact that the researched sample had low income.

Mother and household head schooling was significantly lower in the lower groups. A study that assessed the relation of anemia in infancy and socioeconomic group, indicated by the level of schooling of household head, showed that although none of the groups was immune to the occurrence of anemia, the prevalence was inversely proportional to the level of household head schooling ${ }^{(10)}$. This result suggests that this variable is certainly associated with greater chances of employment, and consequently, higher income and better conditions of life, which is an important factor to protect against anemia occurrence. In fact, most studies show association between greater anemia prevalence and lower schooling of fathers, but not with schooling of mothers ${ }^{(2,4-5,11)}$. Some studies found association between anemia in children and schooling level of mother ${ }^{(6,12)}$. In this case, beyond the relation to better social conditions, it has been also associated with better maternal ability to care.

The presence of bathroom inside the household is a characteristic of the ways of living that differed considerably among the social groups. The studies assess different variations of this variable. When it was understood as the presence of a toilet with or without a flush in the household there was significant association with the presence of anemia ${ }^{(2,4)}$. The presence or absence of a bathroom in the household did not show association with anemia ${ }^{(5)}$. Also in ways of living, piped water and sewage represented different access of social groups to public services of sanitation. Its relation to anemia seems obvious, since greater prevalence of intestine parasites is directly associated with poor sanitation. This is a typical condition of areas where people in the lower groups of Brazilian society live ${ }^{(7)}$, and justify the greater frequency of children's morbidities. The results, however, are contradictory. Only one study ${ }^{(4)}$ assessing this variable found prevalence of anemia significantly higher in children living in houses without piped water, whereas others did not find this association $^{(5-6,12)}$.

Mean age of household head increased significantly from the lower to the upper group. The reason might be similar to that of the schooling variable, that is, the greater the age, the better the professional and financial stability. Regarding maternal age, the proportion of adolescent mothers was assessed among the social groups because, together with the inexperience in caring for children, adolescents present increased risk of having premature children, with low birth weight, predisposing children to have lower iron store and, consequently, greater risk of anemia. However, difference was not observed in this aspect. Although some studies have seen association between anemia and this variable ${ }^{(2,4)}$, this association was not confirmed by other studies ${ }^{(3,5)}$.

The size of families did not differ among the groups, but the number of children was significantly lower in the upper group. Association of this variable 
with anemia has been analyzed in several ways, with different results: no association between anemia prevalence and number of people living in the house and of children below 6 years of age ${ }^{(4)}$; greater risk of anemia for children with two or more siblings below 5 years of age ${ }^{(3)}$. A study assessing the efficiency of fortified cow's milk for anemia prevention in children below 4 years of age showed a significantly greater decrease of anemia in families with only one child below 5 years of age, in comparison to those with two or more children below 5 years old ${ }^{(13)}$. For these authors, data suggest that in families with more young children, the demand for food is greater and they might not be always available in reasonable quality and quantity. Furthermore, it is known that the greater the number of small children in families, the less attention is given to each of them, including care regarding food and health in general ${ }^{(3)}$.

Maternal insertion at work was high and did not differ among the groups. Its relationship to anemia could be analyzed in two ways: lower risk of anemia because a paid job can increase/complement family income and though determine better conditions of life, or greater risk due to difficulties in maternal care ${ }^{(14)}$. Studies however, have not found association between this variable and the development of anemia ${ }^{(2,4)}$.

Anemic children characteristics did not show differences according to social groups, although there was a mild tendency of worse nutritional status, less access to medical appointments, greater frequency of health problems, and presence of intestine parasites in the less favored groups. This result point out the importance of a social approach to the problem of anemia, not only as a problem focused on the biological aspect ${ }^{(7)}$.

\section{FINAL CONSIDERATIONS}

This study was carried out with the perspective of social stratification, considering the difficulties of working with the concept of social class $^{(15)}$. Despite this fact, composed indicators were used and it must be considered the limitations regarding the risk of not having chosen the variables for building the groups appropriately. Even facing those technical limitations, it was tried to explore as much as possible all the chances of getting closer to the profile of social reproduction revealed by the groups. Indeed the theoretical bases helped to explain how each social group creates a certain pattern regarding the development of anemia in children. The results reiterate that the anemia in infancy is related to inappropriate ways of working of the lower social groups and consequently inappropriate ways of living. These evidences should subsidize the interventions that aim at reaching the origin of the problem.

This fact is especially important when considering relationship theory/practice in the field of collective health, because the field of public health has traditionally based its proposals for intervention "in a knowledge that gives priority, or in fact reduces the explanation of the health/disease process to a simple biological determination, centered on the human body. This would limit and confine finding concrete possibilities to "solve" the problem and may even hide it"(7).

\section{REFERENCES}

1. World Health Organization. Iron deficiency anaemia. Assessment, preventing, and control. A guide for programme managers. Geneva: WHO/NHD/01.3; 2001.

2. Neumann NA, Tanaka OU, Szarfarc SC, Guimarães PRV, Victora CG. Prevalência e fatores de risco para anemia no Sul do Brasil. Rev Saúde Pública 2000 fevereiro; 34(1):56-63. 3. Silva LSM, Giugliani ERJ, Aerts DRGC. Prevalência e determinantes de anemia em crianças de Porto Alegre, RS, Brasil. Rev Saúde Pública 2001 fevereiro; 35(1):66-73.

4. Santos I, Cesar JA, Minten G, Valle N, Neumann NA, Cercato E. Prevalência e fatores associados à ocorrência de anemia entre menores de seis anos de idade em Pelotas, RS. Rev Bras Epidemiol 2004 dezembro; 7(4):403-15.

5. Matta IEA, Veiga GV, Baião MR, Santos MMAS, Luiz RR. Anemia em crianças menores de cinco anos que freqüentam creches públicas do município do Rio de Janeiro, Brasil. Rev Bras Saúde Matern Infant 2005 julho-setembro; 5(3):349-57.
6. Monteiro CA, Szarfarc SC, Mondini L Tendência secular da anemia na infância na cidade de São Paulo (1984-1996). Rev Saúde Pública 2000 dezembro; 34(6 Supl):62-72.

7. Martins IS, Alvarenga AT, Siqueira AAF, Szarfac SC, Lima FD. As determinações biológica e social da doença: um estudo de anemia ferropriva. Rev Saúde Pública 1987 abril; 21(2):73-89. 8. Laurell AC. A saúde-doença como processo social. In: Nunes ED. (organizador) Medicina Social: aspectos históricos e teóricos. São Paulo (SP): Global; 1983. p.133-58.

9. Queiroz VM, Salum MJL. Operacionalizando a heterogeneidade do coletivo na releitura da categoria reprodução social. São Paulo (SP): Departamento de Enfermagem em Saúde Coletiva, EEUSP; 1997.

10. Monteiro CA, Szarfarc SC Estudo das condições de saúde das crianças do Município de São Paulo, SP (Brasil), 1984-1985. V. Anemia. Rev. Saúde Pública 1987 junho; 21(3):255-60.

11. Assis AM, Santos LMP, Martins MC, Araújo MPN, Amorim $\mathrm{DQ}$, Morris SS et al. Distribuição da anemia em pré-escolares do semi-árido da Bahia. Cad Saúde Pública 1997 abril-junho; $13(2): 237-44$ 
12. Lima ACVS, Lira PIC, Romani SAM, Eickmann SH, Piscoya MD, Lima MC. Fatores determinantes dos níveis de hemoglobina em crianças aos 12 meses de vida na Zona da Mata Meridional de Pernambuco. Rev Bras Saúde Matern Infant 2004 janeiro-março; 4(1):35-43.

13. Torres MAA, Lobo NF, Sato K, Queiroz SS. Fortificação do leite fluido na prevenção e tratamento da anemia carencial ferropriva em crianças de 4 anos. Rev Saúde Pública 1996 agosto; 30(4):350-57.

14. Frota MA, Barroso MGT. Repercussão da desnutrição infantil na família. Rev Latino-am Enfermagem 2005 novembro-dezembro; 13(6): 996-1000.

15. Lombardi C, Bronfman M, Facchini LA, Victora CG, Barros FC, Béria JU, Teixeira AMB. Operacionalização do conceito de classe social em estudos epidemiológicos. Rev Saúde Pública 1988 agosto; 22(4):253-65. 